\title{
Long-term field experiments in the crop production and agroecology
}

TAMÁS KISMÁNYOKY

University of Pannonia, Georgikon Faculty, Keszthely, Hungary kis5556@ella.hu

\section{Summary}

In Hungary, there are 57 LTFEs included 13360 plots of them 51 trials elder than 20 years, more than 50 years are 32 trials and 6 less than 20 years old. Compared to the 2003 statistical data, some 26 LTFEs ceased to operate in the course of the last 15 years. All research workers and scientist have to do the best to preserve the recently still existing LTFE's. This paper presents the list of the currently active LTFEs with some comments including the locations, year of setting and the number of plots.

Keywords: long term, internationale cadastre, domestic cadastre

With respect of the long term field experiments, Hungary belongs to the international forefront. The acquired multi-year data and experiences provide a remarkable assistance to answer the following challenges: changing market requirements, newly emerging environmental problems and the risk of climate changing. It is the responsibility of the present and future generations to preserve this scientific heritage (Láng, 2009).

Why the LTFE are important?

LTFE have always existed in those places where their importance is recognized. They are the source of information on the factors that influence soil fertility and its sustainability (Körschens, 2000). These experiments can be considered as living laboratories that allow us to study the physical and biological parameters of the agricultural environment and that provide scientist and policy-makers basic information for monitoring and controlling the environmental mechanisms.

Most LTFE in Hungary and elsewhere too, were set up to study the effects and interactions of crop rotation and continuous cropping, organic and mineral fertilizers, nutrient balances, microelements, liming, soil tillage, water management, plant protection, the nutrient responses of new varieties etc. The variability of years and the impact of agro-climatic factors on crop production can be studied in the field in long term experiments, where consecutive years represent not only statistical replications, but each individual year also provides new information. The 
older the experiment the more scientific data are generated. The effect of climate change can be estimated reliability from the results of these experiments by comparing long term data from different locations. Long term databases also form the background for computer models to promote the sustainable development of agriculture and the environment.

Agronomical experiments are like conversation with the plant, the soil and the studied medium in general. The results of LTFE are valid for a given territorial unit and a given time interval, but we want to use this information as an exact scientific basis in agronomical agro technical advisory services for a longer area and for a longer period. Consequently, the extension and validation of the measured point and minute information in space and time is obligatory (Várallyay, 2009).

LTFE experimentation and monitoring are vitally important in understanding the changes that are occurring in the environment and the way they interact with agriculture and natural ecosystems. Much attention today is given to modeling, often thought to be a reliable way of predicting future events, but models are only as good as the data on which they are based and reliable data for modeling biological systems need long term experiments (Leigh and Johnston, 1993).

LTFE are the source of such information from which we can learn a lot about the factors that influence soils fertility and its sustainability. In most cases effects and interactions can be understood only from LTFE data even if different soil and climatic conditions are compared to each other. These information's are valuable for farmers, extension consultants, decision makers as well as scientists either in local or a wide scale concerned (Kismányoky, 2009).

Soil processes take place very slowly, therefore LTFE trials are need to investigate the influence of variable factors. LTFE fertilizer trials exploring both the yields of agricultural crops as well as the influence of fertilizers on the soil properties and soil indicators, the sustainability and the environment. LTFE are an indispensable basis of our knowledge of predominantly practical solutions for sustainable land use. A large proportion of up to now still insufficiently solved problems can be clarified exclusively using long term experiments.

Because of longevity, it is fairly costly to maintain them. But their scientific and practical value is immeasurable in the environmentally friendly land use and crop production, because this information cannot be replaced by other means (Debreczeni and Körschens, 2003).

What is LTFE?

Long term field experiments (lately agrecosystem LTE) can be defined as a large-scale, more than 20 years old field experiments in which we study 
the different factors of crop production, nutrition cycles and the agroecological effects on agronomy, The common characteristic of the LTFE is that the same treatments are set on the same plots on the subsequent next years, in order to study the long term effects of the different treatments. The duration of the LTFE depends of the aim of the research work and it may change from decades to more than 150 years (Berzsenyi, 2015).

The most essential common property of LTFE's which separates all other experiments, that the effects of the treatments are observed on an unchanged monitoring unit more successive time, where we investigate the difference of treatments between the two observation time, and/or what is the difference between more than two observation time in the sections overall (Sváb, 1981).

\section{LTFE global outlook}

The oldest long term experiments that have run continuously since their foundation are 160 years old now. They were established at Rothamsted in England by the Rothamsted Experimental Station's founder J. B. Lawes and J. H. Gilbert in 1843. The experimentation in England has focused attention on long term field experiments, and such experiments were soon set up in other lands, too. According to our knowledge, 25 LTFE in the world are already older than 100 years, and 11 of them can be found in England, three in Denmark, two in France, two in Germany, two in Ukraine and five in America. The number of LTFE that are younger than 100 years but older than 10 years number nearly 600 in the different countries of the world, most of them can be found in Europe.

To compiling of the long term experiments in the European countries was done by Körschens (1994, 1997, 1999, 2000). Further interesting surveys of the world's LTFE can be found in the works of Mazur et al. (1993), Debreczeni and Debreczeni (1994), Leigh and Johnston (1994), Merbach et al. (1999), Smith et al. (2001), Láng et al. (2002).

The world long term experiments of the world are summarized in Table 1.

From the Table 1 some conclusion can be drawn: The research work with field experiments started in the XIX. Century in Europe and the US in those country where the agriculture were intensive and highly developed (Germany, France, Denmark, England). The most LTFE were founded in the $20^{\text {th }}$ century, when the development of the natural sciences, machines, instruments, telecommunications, informatics, etc. was excessively rapid and the innovations have been moved to practical farming. In the second half of the century in the West European countries the artificial fertilizers and plant protection chemicals were used much earlier and in higher amounts than elsewhere, resulting destructive 
environmental impacts. The rate of unfavorable changes in soil properties and groundwater pollution was remarkable. LTFE with a great past could provide well-grounded and reliable information about the sources of pollution in landscape protection areas and answers to the decision makers.

Most of the LTFE are in Germany (100), Hungary (83), Russia (62), Sweden (16), GB (19). According to these facts we can reasonably say that Hungary is a great power" regarding the LTFE's.

Table 1. The world long term experiments of the world

\begin{tabular}{|c|c|c|c|c|c|}
\hline Continents, countries & $10-20$ & $20-50$ & $50-100$ & $>100$ years & Total \\
\hline Europe & 24 & 292 & 81 & 20 & 417 \\
\hline Afrika & & 32 & 37 & & 69 \\
\hline Asia & & 28 & 7 & & 35 \\
\hline Australia & & 7 & 14 & & 21 \\
\hline Canada & 1 & 8 & 4 & & 13 \\
\hline USA & & 33 & 17 & & 56 \\
\hline South America & & 9 & 1 & 5 & 10 \\
\hline World total & 25 & 409 & 161 & 25 & 620 \\
\hline Austria & 1 & 6 & 2 & & 9 \\
\hline Bulgaria & & 6 & & & 6 \\
\hline Czech Rep. & 3 & 12 & & & 15 \\
\hline Denmark & & 5 & & 3 & 8 \\
\hline France & & 3 & & 2 & 5 \\
\hline Germany & 6 & 70 & 22 & 2 & 100 \\
\hline Hungary & 5 & 75 & 2 & & 83 \\
\hline Netherland & & 8 & 7 & & 15 \\
\hline Poland & & 11 & 5 & & 16 \\
\hline Romanie & 1 & 13 & & & 14 \\
\hline Spain & 1 & & & & 1 \\
\hline Sweden & & 13 & 3 & & 16 \\
\hline Ukraine & & 12 & 1 & 2 & 15 \\
\hline
\end{tabular}

Source: Debreczeni and Körschens (2003)

LTFE Hungarian situation

Although the original scientific and practical aims of the LTFE set up in Hungary are varied, they all have something in common; they all based on so hypotheses which make them suitable for a long term investigations and for the collection of exact scientific information's on ecological processes and trends. Besides their scientific value, the benefit of LTFE is also manifested in education: undergraduate, $\mathrm{PhD}$, vocational training, extension service etc. This is true all of the LTFE which serve as an open-air demonstration sites for scientists, students and farmers, alike.

In 2004 the Plant production, Soil science and Agrochemical Committee of the Hungarian Scientific Academy made a survey about the situation of domestic LTFE's. The purpose of the survey was clearly to create one kind of LTFE cadastre (Kismányoky and Jolánkai, 2009). The 
same survey was carried out in 2017, as well. The following table (Table 2) summarizes the domestic, currently operating LTFE experiments.

Table 2. Main data of the Hungarian National Long Term trials (2017)

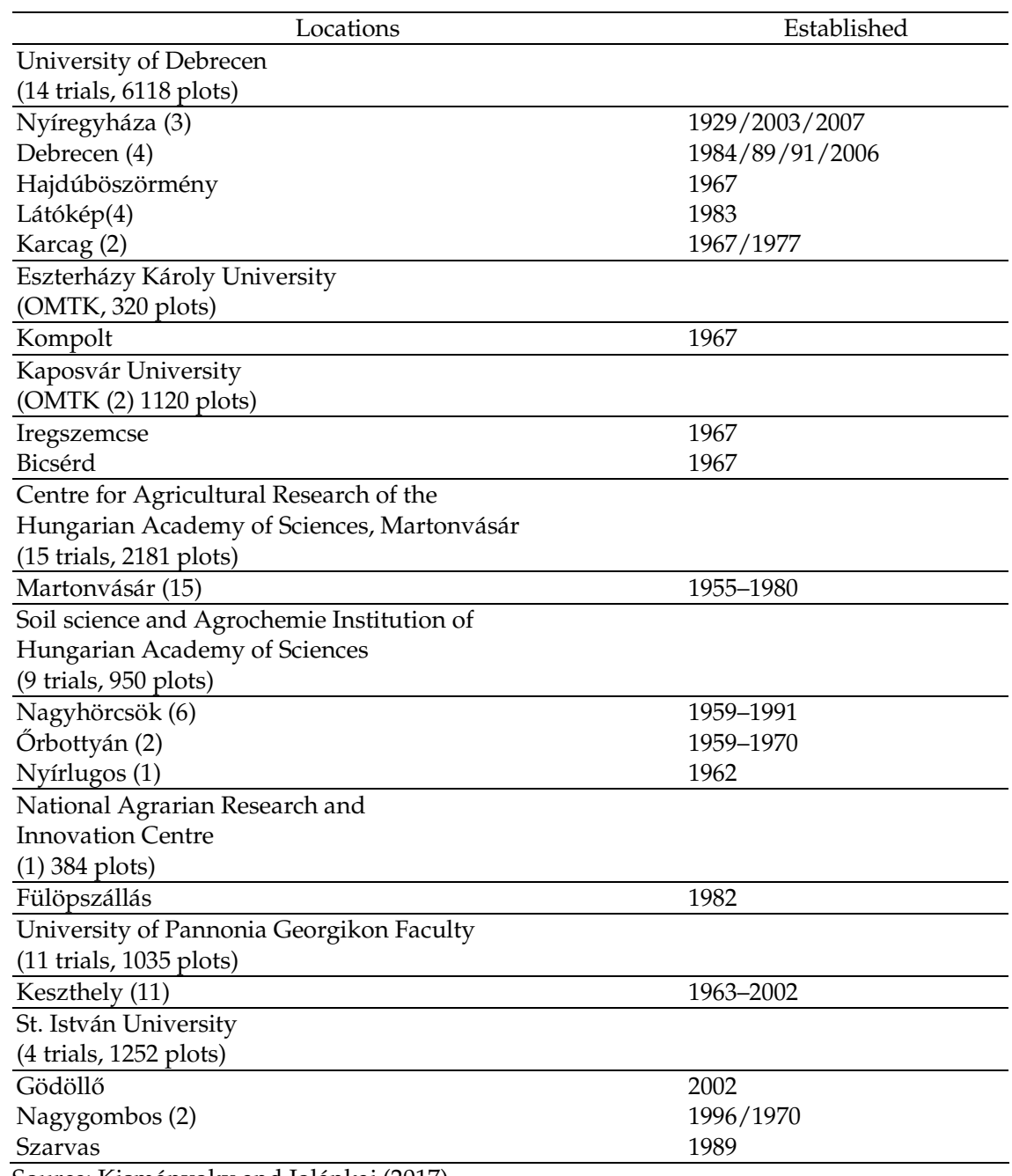

Source: Kismányoky and Jolánkai (2017)

On the bases of the data had been requested from the different institutions concerned, it is concluded that now in Hungary there are 57 LTFE included 13360 plots of them 51 trial elder than 20 years, more than 50 years are 32 trial, and less than 20 years 6 trials were founded. Compared to the 2003 yearly statistical data, some 26 LTFE ceased to operate in the course of the last 15 years. This decreasing is mostly due to 
the decline of the National Long term Field Fertilization Trials, which expiry causes irreplaceable losses to the agronomy research and to the whole society. The research workers and scientist everything have to be done to preserve the recently exist above LTFE's. The experiments older than 20 years should be nationally protected! These LTFE's are very important and held accountable national and international relations, as well. The resources needed to sustain the LTFE far from paying off and the knowledge of the generations after us grows.

\section{References}

Berzsenyi Z. (2015): Növénytermesztési Kísérletek tervezése és értékelése. Tartamkísérletek 442-444. Agroinform Kiadó. Budapest.

Debreczeni, K.-Körschens, M. (2003): Long term experiments of the world. Archives of Agronomy and Soil Science. 49: 465-483.

Kismányoky T. (2009): A tartamkísérletek jelentősége a növénytermesztés kutatásában. V. Növénytermesztési Tudományos Nap. MTA-AONövényterm. Biz. Akadémiai Kiadó. Budapest. 21-27.

Kismányoky T.-Jolánkai M. (2009): A magyarországi tartamkísérletek. [In: Debreczeni K.-Németh T. Az Országos Mútrágyázási Tartamkísérletek (OMTK) kutatási eredményei (1967-2001).] Akadémia Kiadó. Budapest. 2534.

Kismányoky T.-Jolánkai M. (2017): A magyarországi tartamkísérletek felmérése. (A survey on the long term trials of Hungary). Report for the Government. Academy of Sciences.

Körschens, M. (2000): IOSDV Internationale organische Stickstoffdüngungsversuche. UFZ- Bericht No/15/2000 Leipzig-Halle GMBH. 192.

Láng I. (2009): Előszó. [In: Debreczeni K.-Németh T. Az Országos Mútrágyázási Tartamkísérletek (OMTK) kutatási eredményei (1967-2001).] Akadémia Kiadó. Budapest.

Leigh, R. A.-Johnston, A. E. (1993): Long term experiments in Agricultural and Ecological Science. (Preface. Proceeding. Rothamsted. CAB INTERNATIONAL

Sváb J. (1981): Tartamkísérletek tervezése és értékelése Biometriai módszerek a kutatásban. Mezőgazdasági Kiadó. Budapest. 230. 